\title{
A middle Eocene seep deposit with silicified fauna from the Humptulips Formation in western Washington State, USA
}

Frida Hybertsen and Steffen Kiel

Acta Palaeontologica Polonica 63 (4), 2018: 751-768 doi:https://doi.org/10.4202/app.00525.2018

Carbonate blocks with silicified fossils were recovered from a newly recognized cold seep deposit, the Satsop Weatherwax site, in the basal Humptulips Formation, along the West Fork of Satsop River in Washington State, USA. The petrography and the stable carbon isotope signature of the carbonate, with values as low as $-43.5 \%$, indicate that these carbonate blocks formed at an ancient methane seep. The fossils recovered from this block include five vesicomyid specimens, two fragments of a thyasirid, five specimens of the peltospirid Depressigyra, two specimens of the hyalogyrinid Hyalogyrina, 25 specimens of the neritimorph Thalassonerita eocenica, and three limpet specimens of two different species. Five species can be described as new: Nuculana acutilineata (Nuculanoidea), Desbruyeresia belliatus (Provannidae), Provanna fortis (Provannidae), Orbitestella dioi (Orbitestellidae), and Leptochiton terryiverseni (Polyplacophora). Other fossils recovered from this site are numerous serpulid tubes, echinoid spines, one brachiopod fragment and two neogastropods. Almost all species recovered belong to extant genera and the fauna has a modern character, but are different from species found in younger seeps in Washington State. This is the first record of an orbitestellid from an ancient cold seep deposit, the first fossil provannids from the Humptulips Formation, and the first fossil record of Desbruyeresia from North America.

Key words: Mollusca, Nuculoida, Caenogastropoda, deep sea, cold seeps, Eocene, Humptulips Formation, USA.

Frida Hybertsen [ frida.hybertsen@nrm.se] and Steffen Kiel [steffen.kiel@nrm.se], Department of Palaeobiology, Swedish Museum of Natural History, Box 500 07, 10405 Stockholm, Sweden.

This is an open-access article distributed under the terms of the Creative Commons Attribution License (for details please see creativecommons.org), which permits unrestricted use, 
distribution, and reproduction in any medium, provided the original author and source are credited.

For Full text $(1,346.8 \mathrm{kB})$ 